\title{
Pain in newborn
}

\author{
Lorenzo Giacchetti ${ }^{1}$, Monika Stablum², Arianna De Martino ${ }^{3}$, Arturo Giustardi ${ }^{4 *}$ \\ From 70th Congress of the Italian Society of Pediatrics, Joint National Meeting SIP, SICuPP, SITIP \\ Palermo, Italy. 11-14 June 2014
}

Recent scientific studies have added more and more consistent evidence that the newborn, even if preterm, is very sensitive to the nociceptive stimulus. The baby responds with a well known physiological, metabolic and hormonal reaction, that, if repeated, may lead to short and medium term negative effects on the newborn. This vulnerability to painful stimulus, especially in preterm infants, can be explained by neurophysiological mechanisms. In spite of a well developed sensory apparatus for nociception, the descending inhibitory systems and their neurotransmitters responsible for nociceptive afferents, are deficient and immature until after the term birth. Behavioral changes and reductions in the volume of some sensitive brain areas were observed in ex preterm infants admitted to the neonatal intensive care unit; the modifications were very similar to those seen in experimental model of rat with same gestational age, exposed to early and repeated painful stimulus [1]. We consider as environmental interventions all steps that can reduce stress in the baby during a painful procedure. A variety of non pharmacologic pain-prevention and relief techniques have been shown to effectively reduce pain from minor procedures in neonates. These include use of oral sucrose/glucose, breastfeeding, nonnutritive sucking, kangaroo care, facilitated touch (holding the arms and legs in a flexed position), swaddling, and developmental care [2]. The involvement of the mother is recommended through skin-to-skin or breast-feeding during a single sampling. Several studies have shown how breastfeeding during a painful procedure reduces the stress in newborn [3].

The prevention of pain in neonates should be the goal of all caregivers, because repeated painful exposures can have deleterious consequences. Neonates at greatest risk of neurodevelopmental impairment as a result of preterm birth are also those most likely to be exposed to the greatest number of painful stimulus in the NICU. We have to

\footnotetext{
* Correspondence: artgiust@tin.it

${ }^{4}$ Department of Neonatology Merano, Italy

Full list of author information is available at the end of the article
}

improve strategies for routinely assessing pain, minimizing the number of painful procedures performed, using pharmacologic and non pharmacologic therapies for the prevention of pain associated with routine minor procedures, and eliminating pain associated with major procedures.

\section{Authors' details}

Department of Pediatrics and Neonatology, Lugano, Switzerland.

${ }^{2}$ Associazione Italiana La Care in Perinatologia, Italy. ${ }^{3}$ Department of Neonatology, Mantova, Italy. ${ }^{4}$ Department of Neonatology Merano, Italy.

Published: 11 August 2014

\section{References}

1. Bellieni CV, Bagnoli F, Perrone S, Nenci A, Cordelli DM, Fusi M, Ceccarelli S, Buonocore G: Effect of Multisensory Stimulation on Analgesia in Term Neonates: A Randomized Controlled Trial. Pediatric Research 2002, 51:460-63.

2. Ferber SG, Makhoul IR: Neurobehavioural assessment of skin-to-skin effects on reaction to pain in preterm infants: a randomized, controlled within-subject trial. Acta Paediatr 2008, 97:171-6.

3. Simonse E, Mulder P: Analgesic Effect of Breast Milk Versus Sucrose for Analgesia During Heel Lance in Late Preterm Infants. Pediatrics 2012, 129:657-663.

doi:10.1186/1824-7288-40-S1-A54

Cite this article as: Giacchetti et al:: Pain in newborn. Italian Journal of Pediatrics 2014 40(Suppl 1):A54.

Submit your next manuscript to BioMed Central and take full advantage of:

- Convenient online submission

- Thorough peer review

- No space constraints or color figure charges

- Immediate publication on acceptance

- Inclusion in PubMed, CAS, Scopus and Google Scholar

- Research which is freely available for redistribution

Submit your manuscript at www.biomedcentral.com/submit
() Biomed Central
() Biomed Central

(c) 2014 Giacchetti et al; licensee BioMed Central Ltd. This is an Open Access article distributed under the terms of the Creative Commons Attribution License (http://creativecommons.org/licenses/by/4.0), which permits unrestricted use, distribution, and reproduction in any medium, provided the original work is properly cited. The Creative Commons Public Domain Dedication waiver (http://creativecommons.org/publicdomain/zero/1.0/) applies to the data made available in this article, unless otherwise stated. 